\title{
THE EFFECT OF THE AGRARIAN REFORM ON THE DEVELOPMENT OF CULTURAL ACTIVITIES IN THE REPUBLIC OF CUBA
}

\author{
Verica Savić ${ }^{1}$, Slobodan Nešković ${ }^{2}$ \\ *Corresponding author E-mail: slobneskovic@gmail.com
}

A R T I C LE I N F O
Original Article
Received: 17 May 2018
Accepted: 15 June 2018
doi: 10.5937/ekoPolj1803971S
UDK 332.2.021.8:316.7(729.1)

Keywords:

Cuban agriculture, agrarian revolution, agrarian model, social production, culture;

JEL: Q10, M24

\begin{abstract}
A B S T R A C T
Cuban socialism's efforts to resolve the "agrarian issue" determined the strategies currently in force and their immediate goals. As part of this process, we examine six aspects that characterize the Island's sociopolitical development: the structure of land ownership, land usage, the agrarian organization, the technological model, the agrarian economy, and the development of rural society. Many challenges remain to shaping comprehensive and coherent economic strategies that encourage sustainable economic growth, facilitate Cuba's international economic integration, and contribute to the efficiency and competitiveness of Cuba's economy while simultaneously safeguarding the revolution's gains in social inclusion and equity. The research is supported by knowledge and results from scientific and professional literature, that is, the findings and scientific results of numerous professional authors who have studied the issues of this work in their books and articles.
\end{abstract}

(C) 2018 EA. All rights reserved.

\section{Introduction}

After the insurrectional triumph against the Batista dictatorship in 1959, the Revolution started as a profound transformation of Cuban society, first political, then social and soon after agrarian. In fact, the many insurrectional political programs were committed to changing the conditions of the Cuban countryside and more precisely to an land reform, as contained in the Cuban radical thought and in the constitutional mandate of 1940. The most prominent of these programs is Fidel Castro's famous Statement of Defense (Castro, 1966).

The Cuban agrarian process has therefore been an inseparable part of the history of the Cuban Revolution and one of its cornerstones. Studying this process means referring to a 50-year history, a daring act that escapes the purpose of this essay and for which we have neither the time nor the space required.

1 Verica Savić, MA., Faculty for Engineering Management Belgrade, Vojvode Mišić Boulevard 43, 11000 Belgrade, Serbia, Phone: +381 63253 335, E-mail: savicverica555@gmail.com

2 Slobodan Nešković, Ph.D., University Business Academy in Novi Sad, Cvećarska 2, 21000 Novi Sad, Serbia, Phone: +381 63391 659, E-mail: slobneskovic@gmail.com 
The socialist strategies implemented at that time gave rise to the peculiar agrarian issue, characterized in part by the high level of nationalization of agricultural activities, the low productivity of labor and means, as well as food insecurity. The solution to this "agrarian issue" of Cuban socialism determines the agrarian strategies in place and their immediate goals. We shall examine below some of the topics of its path.

\section{Materials and methods}

In this research, we specifically deal with Cuban socialism's efforts to resolve the "agrarian issue" and manage numerous challenges of modern agrarian reform in the Republic of Cuba. The research is supported by knowledge and results from scientific and professional literature, that is, the findings and scientific results of numerous professional authors who have studied the issues of this work in their books and articles. During the research, the following principles of scientific knowledge were used: objectivity, systematicity, reliability, scientific accuracy and precision. On the basis of the aim of this research, the combination of chosen methods enable the quality realization of this scientific paper.

In this research methods of analysis were conducted in the classification of complex categories, methods of specialization and after synthesis elaboration, different conclusions were formed. The techniques of classifying different data through literature review, as well as the method of description and generalization, have been applied. Generalization as a synthetic scientific method by which it is learned generally on the basis of the individual was conducted during this research. Using the method of description, we present the results that were obtained by looking at the effects of the initiated process of agrarian reform and its effect on culltural system.

\section{Results}

In this paper authors aim to analyze the transitional socio-economic effects to date and the obstacles Cuban society have faced, to identify the social actors involved, and to reveal, along with the new cooperatives' potential for solving Cuba's historic agrarian problems, the continuing restraints on realizing that potential. This research paper represents an attempt to determine the capacity of Cuban economic system to adapt to challenges of modern agrarial and social reforms.

This paper aims to study the changes that the Cuban economy has undergone in recent years following the rise of Raúl Castro to the position of President of Cuba. The hypothesis is that in its current implementation of economic market reforms, Cuba has sought to accelerate its path to rejoining the global market, portraying itself as an economy highly focused on inflation control, the expansion of microcredit (an instrument to deal with poverty), and tax collection by the State, as its development strategy. In this way, the Cuban economy is positioning itself as a potential pole to attract foreign investment. To achieve the objective and hypothesis described here, this paper draws on an empirical-analytical approach to interpret the effects caused by structural reforms in major economic sectors. 


\section{Structure of land ownership and tenure}

As Antonio Garcia used to teach, the characteristic of the domination of large landed estates is not only the high concentration of land in the hands of a few owners or occupants, but also the consequences of relations of exploitation, subordination and exclusion stemming from it, and the corresponding cultural expression, that which he called "the constellation of landed estates" (See: Valdés Paz, 1997, p. 45). The Cuban historical experience could only but corroborate this view. Thus we can see that in the $1950 \mathrm{~s}$, a structure of land ownership characterized by land concentration showed that $57 \%$ of the land were in the hands of 3\% of owners, while $78.5 \%$ (around 126,000 occupants with less than 5 hectares of land) were held by only $15 \%$; and $40 \%$ of them as tenants, subtenants, partners or hold-over tenants.

In fact, the reform of the land ownership structure was the first major structural change implemented by the Revolution in 1959, and since then one of the socioeconomic structures subjected to the greater number of reforms. Since 1959, four reforms have been introduced to the land ownership structure, which can be summarized as follows:

1) First Agrarian Reform Law of May 1959, which eradicated landed estates and foreign ownership of rustic property; eliminated of all forms of non-proprietary ownership; and gave ownership of the land to those who worked it, thus benefiting over 100,000 peasants. Its enforcement, under conditions of severe internal and external struggle, gave rise to a nationalized agricultural sector managed by the State, which comprised $33 \%$ of the country's land.

2) Second Agrarian Reform Law, which was enacted in 1963, once the socialist character of the Revolution had been defined in the context of the political and class struggle of the time. This second Law provided for the automatic nationalization of all properties or buildings with more than 67 hectares. With it, the state agricultural sector gained ownership of $66 \%$ of the land, becoming the basis of the socialist development of Cuban agriculture.

3) Evolution of the 1960s, 1970s and 1980s. from the second half of the 1960s there was a gradual transfer of land from the private sector to the state sector, for reasons of voluntary sales by peasants or purchase for public service, in support of state development plans. The agrarian crisis which began in the 1990s (shortages, decapitalization, collapse of the technological model, lack of agricultural workforce, etc.) brought about to the urgent need to redistribute nationalized land in favor of cooperatives and the peasant sector. This led to a privatization of the ownership structure, reducing its share from $80 \%$ to $40 \%$ of the land.

4) Fourth Agrarian Reform initiated in 2008. The difficult conditions for agricultural recovery in state or recently privatized lands gave rise to a growing stock of idle lands, raising the urgent need for their redistribution under usufruct conditions to new peasants, traditional peasants and cooperatives with workforce availability. The trend shown by the evolution of the land ownership structure in the country was the historical condition for the nationalization of rural property, for subsequent redistribution as private, peasant or cooperative ownership. 


\section{Organization of agricultural production}

The successive land reforms and agricultural development strategies of each period have influenced the evolution of the Cuban agrarian organization, on behalf of novel forms of organization such as state enterprises and cooperatives. A more detailed examination by sector could be illustrative.

\section{Producers}

Peasant producers with areas of 24 hectares on average were affirmed as individual or family producers through the first Agrarian Reform. Conventionally, agricultural production is classified as: sugar (cañera) agriculture, non-sugar (no cañera) agriculture and livestock production, with their respective subcategories. In 1963, 880 farms managed $66 \%$ of the national lands; and in 1989, 474 state-owned enterprises managed $82 \%$ of the lands. Their number decreased in the 1960s and 1970s, stabilized and increased during the cooperativism process fostered during the 1970s and 1980s, and continued to grow as new beneficiaries in the 1990s and 2000s. In fact, records currently indicate the existence of over 300,000 peasants. Various forms of cooperatives have emerged, with different fates, since the 1960s. Cooperatives of peasant origin currently in operation include: a) Agricultural Production Cooperatives (CPA) collectively owned and established during the 1970 s and 1980 s, which covered as much as $40 \%$ of the peasantry and decreased by various causes throughout the 1980s and 1990s; and b) Credit and Services Cooperatives (CCS), a simple form of cooperation in which a number of individual producers gather for certain common purposes. This latter form of cooperation, which was the most successful in the 1990s and the first choice of peasants, tends to increase as a result of the accession of new beneficiary producers. The transfer projected over a million hectares would be distributed as follows: $32 \%$ for various crops and vegetables; $18 \%$ for forest and fruit; and 50\% for cattle farming (Valdés Paz, 2010).

A particular case is that of cooperatives originated among agricultural workers, as a result of the privatization of the 1990s, known as Basic Units of Cooperative Production (UBPC in the Spanish acronym).. The main feature of state agricultural organizations is the large scale and extremely high concentration of resources, as well as the proliferation of second-tier organizations such as unions, business groups, corporations, agribusiness complexes, etc. 6 As a result of the particular developments described here, today we have an organizational scenario of agricultural production dominated by self-managed companies, with a higher weight of cooperatives in terms of land and number of producers. This scenario entails new organizational designs for the activities aimed at ensuring production (supply, mechanized services and transportation, etc.) as well as technical-scientific services and product marketing (Valdés Paz, 2010).

Also worth mentioning is the organization of the state directorate in relation to agriculture, which has also evolved over time in terms of both its functional structure and facilities: National Institute of Agrarian Reform (INRA) from 1959 to 1975 (INRA in the Spanish acronym), created in mid-1959 for the implementation of the first 
Agrarian Reform Law also played the role of center of the new revolutionary State, performing initially many of the functions and activities that would characterize it later on (see: Valdés Paz, 2010, p. 60).

Ministry of Agriculture (MINAGRI) from 1985 to date, and Ministry of Sugar (MINAZ), which since the 1980s has taken over sugarcane agriculture, as well as their respective territorial delegations. The biggest challenge facing the state directorate of agriculture is to switch from a highly centralized administrative directorate to a decentralized state directorate, the case of the so-called "municipalization" (Valdés Paz, 2010, pp 63-64). This "municipalization" seems to benefit from the following reasons: the organizational scale of all producers is under municipal control; the resources of an agro-ecological production are essentially local; and self-managed producers must measure their management vis-à-vis the market. Future organizational reforms in agriculture will need to overcome the historic contradiction between an essentially territorial activity and a vertical organization; as well as the propensity to base the organizational design on administrative rather than economic criteria; the tendency to base management organization on homogeneous models; and finally define short-term organizational agendas.

\section{Science \& Technology}

Since the beginning of the land reform process in the 1960s, agricultural development has been accompanied by a parallel development of technical-scientific services for agriculture and by basic and applied agricultural research. Late in that decade and early in the 1970s, a true technical revolution was introduced in the agricultural sector, both in services and in agricultural research, to support the development plans based on a resource-intensive technological model. In fact, large organizations of technical services were established with budget funding (institutes, national centers, central laboratories, etc.), with presence throughout the national territory, territorial units of soil and fertilizer services, and hydraulic, phytosanitary, veterinary and artificial insemination services among others.

This development of technical-scientific resources to support the agricultural sector faced economic constraints of different natures, including: the costs of the activities were fully covered by the budget, with no direct contribution to the costs of the companies; research results had a low level of incorporation into production practices; and their impact on agricultural productivity was insufficient. Indeed, much of the beneficial effect of the technical-scientific resources used as services or inputs served to mitigate the lack of manpower or the decrease in productivity. Much of this development of the scientifictechnical structure supported the promotion of a resource-intensive technological model formed by various elements, such as large-scale organization, soil specialization, mechanization, irrigation, use of pesticides, benefit for products, genetic selection, incorporation of new varieties, etc. This conventional model gradually replaced the traditional model prevailing in the 1960s, and more rapidly in the 1970s. This model was in effect until the 1980s, when the economic crisis toppled the intensive model and replaced it by an emerging model, hybrid in nature, composed of elements of the intensive model and other 
agroecological models. The need for a model capable of guaranteeing both the economic and ecological sustainability of Cuban agriculture promoted the widespread implementation of agroecological practices, favored by the smaller scale of producers, the model of peasant agriculture as the most sustainable among the forms of production organization, and an incipient ecological culture (Valdés Paz, 2010, p.69).

\section{Agrarian economy}

From the 1960s to the mid-1980s, agricultural development played the role of "hard core" of national development strategies. The development policies implemented in agricultural production over the 1970s and 1980s should both ensure a steady increase in exports and meet the growing domestic demand. In this aspect there were important achievements: 1) The national agricultural area reached $62 \%$ of the total area, $13 \%$ higher than in 1957 , and the crop area was 2.3 times larger than that existing in the $1950 \mathrm{~s}$; 2) The recovery of the sugar agriculture started in the second half of the 1960s would ensure harvests between 7 and 8 million tons by the end of the 1980s; 3) Diversification and the expansion of non-sugar agriculture enabled ensuring rationed food supply to meet a growing demand. The instruments for this purpose were the Consumers Registry and the so-called portfolio of "Sales control for products". The increase in rice, citrus fruits and tubers production was a particular success (Valdés Paz, 2010, p. 70); 4) In addition, a national level of protein supply was ensured - from meat, milk and eggs - which covered much of the basic needs of the entire population. This entailed a remarkable development and industrialization of cattle, poultry and swine breeding; 5) In 1989, the nutritional status of the population reached the real per capita value of 2,845 kilocalories, 76.5 grams of protein and 46.5 grams of fat; 6) Sugar and non-sugar agriculture succeeded in constantly increasing sugar, tobacco and citrus exports.

\section{Investments in agriculture}

These achievements were underpinned by an accelerated process of modernization through productive investment, equipment and development of infrastructure in all agricultural activities. Between 1960 and 1970, the rate of investment in the sector accounted for 25\% of national GDP. This process required a remarkable and successful effort in personnel development, workforce training, and massive training of secondary and higher education technicians. The crisis of the 1990s produced, among other effects, an accelerated decapitalization of agriculture of not less than $50 \%$ of the basic means, and a decline in productive investment. This affected particularly the level of equipment - for lack of replacement or obsolescence - and the preservation of resources and facilities. This is one of the restrictive conditions that agriculture will have to face to move forward in its recovery.

\section{Marketing of agricultural production}

The marketing of agricultural production began to be organized in the 1960s as a supply and distribution (national and territorial) state system. This system was responsible for the purchase, transport, processing and wholesale delivery of agricultural production to the industry and for domestic consumption. Livestock production was provided 
directly by the food industry. This system based on the allocation of funds required for performing its functions and on the absolute weight of the state sector in agricultural production began to experience lower levels of efficiency until it went into crisis in the 1990s. Its recovery was prevented by conditions contrary to those that originated it. Incidentally, the reemergence in the 1990s of the free market, new brokers and the predominance of private production imposed a more complex and participatory conception of agricultural marketing, but not without bringing with them tensions and variations in the central planning, in the guarantee of social consumption and in the rationing portfolio, which is still pending normalization.

\section{Current challenges in Cuban agriculture}

The technological and productive achievements of the Cuban agrarian economy in the first three decades left unresolved the problems of its inefficiency, seen in the low productivity of means and labor, as well as in the growing need for public subsidies in virtually all its sectors. This showed that the Cuban agricultural model was becoming increasingly unfeasible, both economically and ecologically.

The main causes of this trend were both intrinsic to the agricultural model implemented in the 1960s (nationalization, centralization, inadequate incentive mechanism, insufficient money-commodity relations, etc.) and external, as in the case of the Economy Management and Planning System (SDPE in the Spanish acronym) prevailing in each period. Under current conditions, this new system should incorporate, among other things: greater autonomy of the business sector, planning complemented by the market and a tough financial regime. The agricultural model should adjust to this SDPE or "management model". Precisely, this new model will be responsible for recovering the country's agroexporting capacity and the food security of its population. Among the difficulties facing the implementation of a new model is the absence of a direct workforce in the agricultural sector, as well as the lack of resources by most companies. When this model is defined in all its components, policies to overcome these difficulties will need to be implemented.

\section{Rural development}

Overcoming the issues facing the Cuban rural society was a top priority of the revolutionary program and an inseparable part of the national development strategy. These conditions referred not only to the structure of land ownership and tenure and other means of agricultural production that supported the class structure and to the relations of exploitation, oppression and exclusion that prevailed in the prerevolutionary rural society, but also to the absolute backwardness of rural society in relation to urban society (Harper, 1970, p. 34).

Overcoming these conditions required, first of all, implementing successive land reforms that radically suppressed the Cuban dominant classes, landowners and the agrarian bourgeoisie, as well as the administrations of foreign companies; at the same time, the agricultural proletariat and peasantry proliferated on a large scale. In turn, 
the agrarian transformations in general gave rise to a new occupational structure in the Cuban countryside, the main profiles of which are: individual producers, cooperative producers, manual workers, blue collar workers, technicians, clerical workers, managers, artisans and independent workers.

Despite the advances achieved in leveling the urban and rural areas, over time the rural population has show a downward trend in both absolute and relative terms, increasingly affecting the reproduction of the agricultural workforce. In fact, the workforce had shown a downward trend in almost all production sectors until recent years, when new incentive and land distribution policies promoted the return of direct producers. Rural development favored in particular the incorporation of women in social work with greater independence and as protagonists, as well as of young workers, mostly as skilled labor. Finally, we should mention that a resource-extensive and a resource-intensive agrarian exploitation has left its mark in the rural environment by affecting it with greater soil degradation, water pollution, loss of biodiversity, environmental pollution, etc.

\section{Culture as a Means of Enhancing Growth of the Agriculture}

Previous attempts to distinguish the Cuban ideological variant from that developed in the Soviet Union have had recourse to the notion of "Martían Marxism", which one of the leading comandantes, Ernesto "Che" Guevara de la Serna, is credited with having introduced into the constitution. This implies a Marxism tempered by the insistence of the nineteenth century Cuban poet and revolutionary, José Martí, on resistance to US imperialism being mounted across Latin America. Yet, while the ideas of Martí indisputably influenced the broader ideology of the Cuban Revolution from the outset and the reconciliation of Martí and Marx would come to be regarded as alien to the dogmatism that had led to the installation of socialist realism in Europe, documents pertaining to post-revolutionary cultural policy refer not to Martían Marxism but to Marxist humanism. When detailing the humanistic character of Cuban Marxism, the work of Argentinean writer and politician, Aníbal Ponce, is of particular relevance. In 1935, Ponce undertook a detailed study of the humanism that had arisen in the capitalist world to conclude that class society made the idea of a universal culture impossible. By contrast, Ponce proposed that culture could be understood as a form of social consciousness that encompassed individual consciousness, which could form the basis of a proletarian form of humanism.

Considering the instrumentalisation of culture to the betterment of society, Fidel Castro would elaborate, with ample historical justification, "I don't think there has ever existed a society in which all the manifestations of culture have not been at the service of some cause or concept'. In the specific case of Cuba, he believed, 'Our duty is to see that the whole is at the service of the kind of man we wish to create. [...] I believe that the content of any artistic work of any kind - its very quality for its own sake, without its necessarily having to carry a message - can give rise to a beneficial and noble feeling in the human being" (Lockwood, 1967, p. 11). In emphasising the inherent properties of artworks, Fidel successfully exempted them from the didactic aims that were being enforced in orthodox Marxist circles. At the same time, he veered close 
to a Kantian understanding of artistic enjoyment and the contribution this experience could make to physical and mental well-being, the idealistic roots of which served to further distance him from orthodox materialism. But it is important to note here that, while the pleasure attributed to aesthetic encounters would become closely linked to individualism under bourgeois humanist regimes, reaching its zenith in the Romantic era, in post-revolutionary Cuba, the enjoyment of art was made available to all as part of the collective process of reshaping individual and social consciousness.

As explored in greater detail below, this implied not only (passive) appreciation of but also (active) engagement in creative practice as a necessary step towards building a better world foreshadowed by human desire. But this did not mean that popular enjoyment of art should be confined to mediocre forms. In this regard, a second highly instructive point to be taken from The German Ideology is Marx and Engels's rejection of the Romantic idea of creative activity being confined to unique individuals working within constrained disciplines, which is taken to rely upon the suppression of artistic talent in the broader populace.

The revolutionary idea emerges that the intellectual capacity of the huge breadth of organic intellectuals needs to be encouraged. This precedent for democratizing culture would find easy accommodation with Cuban aims. And, while Cuban conceptions of the proletariat would tend towards the peasantry, rather than the industrial working class, it was generally assumed that access to education and culture would play a vital part in lifting the populace from underdevelopment as part of the desired shift to classless society.

At the same time, while capitalism has consistently been perceived to alienate artistic creation from both its producers and the society in which it is made - thereby diminishing its possible contribution to the betterment of humanity and the achievement of social justice - the Cuban Government continues to argue that socialism recognises the real value of art and literature, giving freedom and material stability to artists while revindicating a social role for culture in ways that will be considered here.

\section{Culture as a form of social production}

While a number of artists, writers and thinkers maintained some kind of praxis under the pre-revolutionary regime of General Fulgencio Batista, this was carried out in an often samizdat fashion that risked punitive measures. Before 1959, Cuban artists were dependent upon the whims of businessmen who commissioned work on the basis of private sales. After 1959, the market was generally rejected as a planning device, and, within the cultural field, it could be claimed that Socialism is the first social regime that emancipates culture from the oppression of money, which means the artist can create not to satisfy the depraved tastes of a handful of gluttons but for the great mass of the people.

Cultural producers were declared free from economic insecurity, allowing them to pursue their art instead of having to rely on sales or earn a living from work other than their creative practice. To this end, it was decided that creative practitioners should have a fixed income equal to other workers. In January 1961, a National Council of Culture (CNC) was established as the central organisation responsible for interpreting 
and implementing the cultural policy of the revolutionary government. At the First National Congress of Writers and Artists in August 1961, the CNC Director of Culture, Vincentina Antuña, alluded to numerous grants being awarded to young artists and writers. At the same event, the poet, Roberto Fernández Retamar, read out the founding statutes of the National Cuban Union of Writers and Artists (UNEAC) and announced the creation of a Literary and Artistic Fund under the new union. Cautioning that this fund should not be envisaged as a total solution to the material problems facing artists and writers, he articulated the hope that intellectual work would shortly be considered akin to manual work, making it worthy of remuneration, which, in turn, would bring about a commitment to the profession of arts and letters.

According to a CNC publication, 1969 saw the implementation of a plan to pay artists a salary and cover the cost of their materials, as part of a mutual agreement between the artist and the state, and the Cuban writer, Ambrosio Fornet, asserts that intellectuals 'were able to create with total autonomy thanks to autonomous institutions and a type of patronage - state subsidy - free from the demands of bureaucracy like that of servitude to the market'. (Fornet, 2004, p. 12). As a consequence of this approach, artists graduating during the 1960s and beyond had a guaranteed place in society and (were) able to devote themselves to creative activities without any concerns or difficulties. In return, many artists repaid the state through their work as teachers within the national art schools or as designers of mass-produced books and periodicals. Artworks shed their commodity character, serving as a means of dissemination (through non-commercial posters and publications) or forming part of the national collection, with the state acting as both sponsor and collector.

In 1961, the process of guaranteeing artists and writers a viable income brought about reorganisation of the Copyrights Institute, which would eventually see a decision being taken to revise copyright laws. Prior to the Revolution, laws governing intellectual property - drawn up on January 10th 1879 and amended in the 1930s - had covered scientific, literary, artistic, dramatic and musical works. On April 29th 1967, while inaugurating projects by female scholarship students at Guane, in Pinar del Rio province, Fidel contemplated the private property claims encompassing intellectual work that had historically prevented the people from accessing useful information. Considering that the country's cultural development could be accelerated by reprinting works from around the world - from North American technical manuals to works of universal literature - he proclaimed the abolition of copyright. At the same time, he renounced Cuba's right to any intellectual property accrued within its borders, on the understanding that provision would be made for those who relied for their survival on royalties from creative work. In October of the same year, this theme was taken up at the preparatory seminar for the Cultural Congress of Havana, which would be staged in January 1968. Convinced of the national and international significance of this stance, the artists and writers present at the seminar willingly relinquished the commercial rights to their work, in return for their recognition within society and the value inherent in the creative act. Accordingly, a resolution was issued on the subject of artists' rights, signalling Cuba's intention to elevate its cultural condition by accessing the world's knowledge. 
At a stroke, the floodgates were open for the liberal reproduction of classic works of literature, sociology, anthropology and economy, freely disseminated around the island in Spanish-language editions of multiple thousands. At the same time, the renunciation of copyright on Cuban works reinforced the material reliance of writers upon the state. It has been observed, however, that 'the importance of such a change can be easily overestimated abroad, where royalties are an essential part of the writer's incentive system. In Cuba, even after the new publishing structures eliminated the need for self-financed editions, royalties did not represent a significant income for most authors (Casal, 1971, p. 457).

In April 1971, the First National Congress of Education and Culture had its original educational remit extended in a bid to foreclose the international dimension of a prolonged cultural crisis (Sarusky, Mosquera, 1979, p. 40). While the victory of orthodox forces in the wake of the congress would disadvantage Marxist-humanist approaches for the remainder of the decade, the gathering of 1,800 delegates in Havana provided the opportunity to reiterate that 'The Revolution frees art and literature from the inflexible mechanisms of supply and demand that rule over bourgeois society. Art and literature cease to be merchandise, and all possibilities will be offered for aesthetic expression and experimentation in its most diverse manifestations (Santana, 1977, p. 51).

And, while decisions about the receipt of support would be politicised in the wake of the congress, support did not, in itself, imply the imposition of any particular criteria. The dissociation of artists from the market economy is consistent across internal and external documents. At the First Congress of the Cuban Communist Party (PCC) in 1975, reference was made to the system of intellectual and artistic remuneration in place that had enabled the Revolution to eradicate the conditions of penury and humiliation in which art had been maintained. This sentiment was repeated four years later, in a report to UNESCO which described Cuba as the only country in Latin America to accept art as a form of social production.

Conceiving art as a form of social production not only implied freedom from material constraints on the part of artists; it also entailed a contribution to the process of forging society. From a situation characterised by social uselessness, the politicised intellectuals of the era came to regard their intervention in public affairs as not only a possibility but also an obligation. Creativity was recognised as playing an essential part in the struggle for dignity, and Fidel affirmed that, like any other workers, artists and writers would have to create wealth, which, in their case, would be measured in terms of the infinite happiness their work produced (Paz, 1997, p. 27).

In 1975, in recognition of the need to adequately reward creators for the fruits of their labours, the PCC re-established intellectual property rights. Accordingly, Law 14, ratified at the National Assembly of Popular Power in 1977, made provision for the moral recognition and juridical protection of copyright on the basis that this would stimulate the development of artistic, literary and scientific creation; it also detailed the remuneration of intellectual work according to guidelines drawn up by a newly formed Ministry of Culture in dialogue with the social agencies representing cultural producers (Casal, 1971, p. 458). 
Significantly, Law 14 prescribed that, following the sale of any work of art, ownership alone would pass to the purchaser, with the author retaining copyright. This contradicts the standard practice of the capitalist world, particularly the USA (with the exception of California), which has historically deprived artists of rights to their work after its sale. In a bid to overcome this in 1971, the art agent, Seth Siegelaub, and the New York City lawyer, Robert Projansky, drew up the Artist's Reserved Rights Transfer and Sale Agreement, a 'model contract, reserving certain rights to the artists, such as entitlement to fifteen per cent of subsequent sales, and the right to borrow the work for exhibitions at certain intervals and to veto loans to exhibitions in which the artist did not want it to be shown (Retamar, 1966, p. 266). In much the same way, the nineteenth century French concept of droit de suite gives artists rights over their work as it passes through the hands of successive owners. On 27 September 2001, the European Union attempted to have directive 2001/84/EC - giving artists continued rights over their work in the event of its resale - accepted across the union, but this legislation remains controversial in the UK.

Consistent with the democratising aims of post-revolutionary cultural policy, the reinstatement of intellectual property rights in Cuba was made subordinate to the broader social need for disseminating cultural works as widely as possible. This means that, where any cultural work is considered necessary for scientific, technical or educational development, a licence can be granted for its reproduction and nationwide distribution, freely and without acrimony over money. Extracts of cultural products may be used without the consent of the author, either with or without remuneration, providing that the author is recognised as the originator of the work. And, while the recent reintroduction of an art market in Cuba starkly illustrates the inequities that quickly result from such a system, the conception of art as a form of social production, and of the artist as an integral member of society, endures (Sarusky, Mosquera, 1979, p. 457).

In summary, then, the recognition of art as a form of social production in post-revolutionary Cuba, with the happiness of man as its ultimate goal, secured for artists both an esteemed place within society and an income that left them free to concentrate on their high-quality productions. In response, creative intellectuals have consistently involved themselves in all aspects of social life. This prompts us to give careful attention to the role of creative intellectuals within our societies, particularly in relation to the ways in which their work is valued within a market economy.

\section{Conclusions}

The history of the Cuban agrarian process in its different periods can be characterized as the transition from reforms to an agrarian revolution and, later, from an agrarian revolution to the agrarian reforms underway. In this course, the Cuban Revolution has succeeded in building the foundations of a peculiar socialist agriculture and transforming rural society on a more equitable and participatory basis. Cuba's economic crisis forced the reshaping of agricultural policy in ways that fortified the position of small farmers. 
The Agrarian Reform Law of 1959 abolished large-scale landholdings, tenant farming, and sharecropping. It established a maximum limit of 100 caballerías (1,340 hectares or 3,311 acres) for sugar or rice plantations or cattle estates. In accordance with the law, the government subsequently would confiscate the land of 4,423 plantations, distributing approximately one-third of it to peasants who worked on it as tenant farmers or sharecroppers, and establishing state-managed farms and cooperatives with the rest. The former owners were offered compensation, based on the assessed value of the land for tax purposes, and with payment in the form of twenty-year bonds. Inasmuch as some US-owned plantations covered land of 200,000 hectares, the law had a significant effect on the Cuban structure of land ownership and distribution. It provided the foundation for a fundamental transformation in the quality of life of the rural population that endures to this day.

The crisis unleashed in 1990 over Cuban society as a result of the fall of european socialism led to the loss of many of the successes accumulated by the agrarian development driven by the Revolution and aggravated almost all its latent deficiencies. Recovering from these impacts and their consequences are a topic on the agenda yet to be addressed. In it the ability of Cuban agriculture to recover its exports, substitute imports and constantly increase the food security of the population is of particular relevance. The promotion of a new agrarian model that enables overcoming the shortcomings and contradictions of the historical model is the biggest challenge. however, a new agrarian model entails a new national system of economic management and planning. The agrarian issue will remain, as it has always been, an essential part of the Cuban socialist project. The challenges posed by the agrarian issue for the future of Cuban society cannot be met without a socialist alternative oriented to self-government and self-management.

One of the most striking elements of post-revolutionary Cuban public policy is the massive effort that was made to unleash the latent creative potential of an entire population. Inspired by Che Guevara and implemented by the National Council of Culture, the aficionados programme continues to encourage hundreds of thousands of Cubans to engage not only in the passive reception of art but also its active production. This has achieved considerable success in demystifying the production of art and in giving rise to a highly culturally literate population. Herein lies the area of post-revolutionary cultural policy with the most consequence for the capitalist world - that the possibility of eroding the gulf between art and society, long ago abandoned by the historical avant-garde, has been realised to a large extent in Cuba. Any contemporary programme seeking to investigate the social value of culture would do well to consider the ways in which cultural participation can be democratised. More than half a century after the triumph of the Cuban Revolution, it seems clear that further research is needed into the emancipatory connotations of aesthetic engagement.

\section{Conflict of interests}

The authors declare no conflict of interest. 


\section{References}

1. Casal, L., (1971): "Literature and Society" in C. Mesa-Lago, ed. Revolutionary Change in Cuba, Pittsburgh, PA: University of Pittsburgh Press.

2. Castro, F., R., (1962): Palabras a los intelectuales (Words to the Intellectuals) in: The Revolution and Cultural Problems in Cuba, Havana: Ministry of Foreign Relations.

3. Castro, F., R., (1995): Manifiesto No. 1 Del 26 de Julio al Pueblo de Cuba, Havana.

4. Consejo Provincial de Cultura, (1961): La Cultura para el Pueblo, La Habana: Consejo Provincial de Cultura.

5. Craven, D., (1992): "The visual arts since the Cuban revolution", Third Text, London: Merlin Press.

6. Fornet, A., (2004): "La Década Prodigiosa: un testimonio personal" in: Maldonado, S., ed. Mirar a los 60: Antología de una Década, La Habana: Museo Nacional de Bellas Artes.

7. Gramsci, A., (1998): The Intellectuals in: Q. Hoare and G. Nowell-Smith, eds. Selections from the Prison Notebooks of Antonio Gramsci, London: Lawrence \& Wishart.

8. Grasskamp, W., Nesbit, M., Bird, J., (2004), Hans Haacke, London: Phaidon.

9. Harper, G., (1970): Cuban and Peruvian Agrarian Reforms: At the Crossroads, University of Miami Law School Institutional Repository University of Miami Law Review 7-1.

10. Lockwood, L., (1990): Castro's Cuba, Cuba's Fidel: an American journalist's inside look at today's Cuba in text and pictures, Boulder: Westview Press.

11. Paz, V., J., (1997): Procesos agrarios en Cuba 1959-1995, La habana: Ciencias Sociales.

12. Retamar, R., F., (2004): "Hacia una Intelectualidad Revolucionaria en Cuba" in: Cuba Defendida, La Habana: Editorial Letras Cubanas.

13. Santana, J., (1977): Política Cultural de la Revolución Cubana: Documentos, La Habana: Editorial De Ciencias Sociales.

14. Sarusky, J., Mosquera, G., (1979): The Cultural Policy of Cuba, Paris: UNESCO.

15. Vásquez, A., S., (1965): Art and Society: Essays in Marxist Aesthetics, London: Merlin Press. 